\title{
Instructional Assessment Practices of Science Teachers in Barbados: Pattern, Techniques and Challenges.
}

\author{
Babalola J. Ogunkola $\mathrm{PhD}$
}

\author{
School of Education, \\ Faculty of Humanities and Education, \\ The University of the West Indies, \\ Cave Hill Campus, Barbados \\ drbeejay@hotmail.com
}

\section{Catherine Clifford $\mathrm{PhD}$}

\author{
Sir Arthur Lewis Community College, St Lucia. \\ ekiwie@hotmail.com
}

Doi:10.5901/ajis/2013.v2n1p313

\section{Abstract}

This study investigated the instructional assessment practices' pattern, techniques and challenges of science teachers in Barbados with a view to providing a baseline data on the state of the art of this important aspect of science teaching. A total of 55 science teachers drawn from 12 out of 22 secondary schools in Barbados constituted the participants in the study. The Self - report data obtained by a survey questionnaire revealed that teachers use similar instructional assessment practices regardless of sex, teaching experience, professional qualification, and academic qualification. Teachers reported using collaborative and formative assessment practices most often although the techniques they reported to use did not greatly reflect this. Idiosyncratic solutions to their systemic challenges do not reflect the teachers' claim of using collaborative assessment practices. Based on the findings, it is recommended that teachers will benefit from professional development activities that promote reflection and collaboration in addressing their instructional assessment challenges on a practical level. Further research is necessary to look into the influence of teacher beliefs and attitudes on their instructional assessment practices.

Key words: Instructional Assessment Practices, Science Teachers, Barbados, Secondary school, Pattern, Techniques, Challenges.

\section{Introduction}

Given the important role of assessment in teaching, it is essential that educators pay close attention to the process of assessment and the decisions that teachers make regarding their assessment practices (Chiappetta et al. 1998). The science teacher is in the position to both initiate and implement changes in classroom assessment and to make decisions regarding what assessment practices are significant and worthy to be used (Bell 2007). Assessments can provide information to potentially optimize teaching and learning (Nitko 2004), and can empower teachers to improve their teaching, motivate their students to learn, modify students' study habits, change students' attitudes, and stimulate students to develop new interests and directions for learning (Trowbridge et al. 2004). It is therefore worth investigating the instructional assessment practices of science teachers particularly in the Caribbean 
region. In Barbados and the Caribbean region, secondary school science teachers engage in teaching the science subjects Biology, Chemistry, Physics, Integrated Science, Agricultural Science and Human and Social Biology (HSB). These subjects (except HSB) are assessed by means of an SBA (School Based Assessment) component and paper and pencil tests at the CSEC (Caribbean Secondary Education Certificate) by the Caribbean Examinations Council (CXC). HSB is assessed only by paper and pencil tests. Science teachers are responsible for the SBA components while CXC sets the written components. In Forms one to three the teacher is solely responsible for his/her assessment practices with minimal guidance and support from CXC or the local Ministry of Education.

Although teacher preparation programmes do introduce trainee teachers to a variety of assessment techniques, there is insufficient time for such programmes to allow teachers to develop expertise in using these techniques. Also, trainee teachers are mainly assessed by traditional techniques such as paper and pencil tests. Consequently, when teachers enter the classroom and are faced with myriad tasks and challenges they may resort to the techniques that they are familiar with and those that are easier to use in their classroom context. As time elapses, teachers may develop a routine which becomes their practice and teachers may then be unwilling to change their practice.

Therefore, knowledge of good assessment practices does not automatically translate to good assessment practices in real life. This paper looks into what assessment practices science teachers report using and the reasons for their assessment practices.

\section{Theoretical framework}

Although assessment forms an integral part of all teacher decisions and teaching (McMillan 2007), assessing student learning is no easy task. Assessment is inseparable from teaching and learning (Bass et al. 2009; Clymer and William 2007; Loucks-Horsley 1989; National Research Council 1996; Wiggins 1992), enhances instruction and promotes learning (Reynolds et al. 2009). In light of this connection between assessment and instruction, the term assessment in this paper refers to instructional assessment.

The current "hands-on, minds-on" trend in science education require that assessments have the following characteristics: indistinguishable from instructional tasks (Atkin et al. 2005); emphasis on interconnections between knowledge, understanding and skills; focus on developing depth of understanding as well as mastery of knowledge; and emphasis on the process of obtaining answers as well as the accuracy of the answer or performance (Loucks-Horsley 1989). The suggestions that assessments move away from proving learning to improving learning, and focus less on measurement and more on judgment (Bell 2007) are worthy of consideration by Caribbean educators.

Assessment is a multidimensional process of collecting and interpreting educational data which includes: data use, data collection, methods of collecting data and users of data (National Research Council 1996). Other writers for example (McMillan 2007) have assigned different names to the components of the assessment process. He describes the components of classroom assessment as including: purpose, measurement, evaluation and use. Another writer (Popham 2008) asks the questions; why assess? What to assess? How to assess? Do Caribbean science teachers' assessment practices reflect all these facets of assessment? When done before instruction, assessments can provide the teacher with information pertaining to students' prior knowledge, motivation and interests which can be used to guide the planning of instruction. Teachers can use formative assessment to gauge students learning while the lesson progresses in order to modify their teaching plans and to give appropriate feedback to students.

Assessment of student learning at the end of a teaching cycle or summative assessment (Sato and Atkin 2007) is important for teachers to establish how well the students have learned the material, whether they are ready for the next level, whether changes in instruction are necessary and what grades to 
assign students as well as reporting on students' progress to administration and parents.

The methods used to collect data commonly called instruments, tools or techniques include paper and pencil tests, performance tests, interviews, portfolios, performances, observations, transcript or student record analysis, and expert reviews of educational materials. The techniques used are guided by what is being measured and what decisions the data will inform. The techniques selected for measurement are also affected by the assessment strategy being applied (norm-referenced or criterion referenced).

The current conceptualization of assessment as a multidimensional process has led to new trends in assessment. Instead of using a single method to measure student learning, all aspects of science achievement should be measured using a variety of data collection methods. In this context, the quality of the programme experienced by students is reflected in the assessments. There is also a drive towards using authentic assessment. Authentic assessment focuses on application of scientific knowledge and reasoning in real world situations. Additionally, in terms of validity, this new meaning of assessment has led educational measurement specialists to give more consideration to the social and educational consequences of data interpretation instead of being concerned only with the technical quality of educational data.

\section{Assessment practices of teachers}

One major influence on teachers' assessment practices and grading decision making is external pressures such as that exerted by high-stakes examinations (McMillan 2007; Osborne et al. 2003), grading policies, and parents' demands. Teachers may decide to use items that are similar to those used in highstakes examinations in their classroom assessments. It has been suggested that heavy emphasis on highstakes assessment may reduce teachers' use of formative assessments (Cowie and Bell 1999).

Formative assessment practices can be useful to science teachers in helping students develop scientific habits of mind and to monitor students' formation of misconceptions and concept development (Sato and Atkin 2007). The quality of the feedback is important if learning is to improve. Feedback that focuses on what the learner needs to do for improvement and how to go about achieving such improvement can result in considerable improvement in learning (Black and Wiliam 1998; Kluger and DeNisi 1996 cited in Clymer and Wiliam 2007).

Teachers' assessment practice should modify instruction to meet their students' learning needs based on evidence from formative assessments as well as using that information to assign a final grade for a specific teaching period (Clymer and William, 2007). In support for formative assessment results being used for assigning grades, Clymer and William (2007) conducted a pilot study on grading in $8^{\text {th }}$ grade physical science in 2005 - 2006. In this model of assessment, the grade is not final until the end of the marking period. The researchers report that the participants in the study focused more on learning and that students were more involved in monitoring their own learning. There was also an increase in seeking help from the teacher and peers. Understanding the content became more important than getting a high percentage (the opposite of the situation in the Caribbean region).

Teachers may also assess student learning by using peer assessment and self-assessment. The use of peer assessment can provide students opportunities to explain their understandings to their peers and self- assessment forces the student to reflect on his or her own learning. Rubrics prepared by the teacher or teacher and students can be used to reveal the required expectations of students' work. Other assessment practices that are useful to teachers include listening to students' talk while they work in order to gain insight into student's understanding and learning from the successes of other teachers (Sato and Atkin 2007). 


\section{Attitude of teachers to assessment practices}

A major influence on teachers' assessment practice decisions is their beliefs and values (McMillan 2007). The beliefs and values of teachers are reflected in their philosophy which in turn guides how they teach and assess student learning. However, the teacher's philosophy and the curriculum aims and pressures are not always in harmony and conflicts arise. When teachers are faced with conflict between their philosophy of teaching and learning and the pressures they encounter, they may resort to giving in to the demands of the pressures at the expense of assessing students' understanding.

It is very difficult for teachers to change their attitude to classroom assessment practices (Sato and Atkin 2007). The authors note that such change may be facilitated only by careful reexamination of fixed routines and techniques and even the teacher's self-image. Teachers may have great difficulty in giving up the familiar and comfortable practices. Their personal beliefs can greatly influence their assessment practices. While some teachers believed in giving students opportunity, regardless of the time taken to master major concepts and skills others felt that this practice was unfair to those who were able to complete their work to the desired standard in less time. Some teachers feared that the more able students would lose interest while other teachers wanted to reward those students who demonstrated care and precision (Sato and Atkin 2007). The authors noted that teachers were willing to adapt what worked for other teachers to match their own beliefs about assessment.

\section{Changing teacher assessment practices}

The key to changing classroom practice is to allow teachers opportunities for reflecting on their practices and to question the purposes and uses of their practices through collaboration (Henze et al. 2007; Marx et al. 1994; Ratcliffe et al. 2005). However, admitting to the need for change and becoming willing to relinquish the comforts of familiarity can be an agonizing process for teachers (Sato and Atkin 2007). The authors proposed three guidelines which educators can use to provide support for practicing science teachers. It is suggested that teachers should be encouraged to pinpoint some of the assessment practices that interest them, scrutinize their teaching, and plan changes to reflect the practices of interest to them. Choice of practice has the advantage of allowing natural variations in "teachers' beliefs, values, interests, and comfort levels with change" (Sato and Atkin 2007, 79).

It is also suggested that the change process begin by looking at the teachers' beliefs and practices instead of being guided by abstract 'best practices'. Teachers need help in finding out what works for them, what they can change and how they can change. The authors conclude that teachers' choice of practices is ultimately determined by their personalities and values, and their ideas of the kind of teacher they want to become.

Thirdly, Sato and Atkin (2007) recommend that teachers collaborate in sharing expertise, exchanging practices and engaging in discussions to reveal new possibilities. They see the need for teachers to build trust and to develop reflective thinking. In order for these guidelines to be effectively used teachers need time to integrate the ideas into their classroom practices. Showing the teachers what is possible is not sufficient for effecting change.

While Sato and Atkin (2007) suggest some commendable guidelines teachers need to understand the underlying assumptions of the curriculum and to compare these to their own assumptions guiding their teaching and learning when making decisions regarding their assessment practices (Blumenfeld et al. 1994). It could hereby be argued that formal teacher training in the Caribbean context inadequately mimics the "real" classroom and teachers (particularly in the Caribbean) do not have adequate professional support to address their assessment needs. Therefore science teachers in the Caribbean do not meet the important demands of instructional assessment. 
Literature in the area of assessment in science education that is contextual to the Caribbean is quite scarce. Very few Caribbean authors have explored this area and it is imperative that Caribbean educators realize and address this void. Griffith (2006) in an exploration of the practical difficulties resulting from the design of a course in classroom assessment in Jamaica suggests that assessment procedures and instruments must provide both teachers and students with feedback that is useful in improving student learning. Griffith (2006) notes that both assessment for learning and assessment of learning are important in constructivist classrooms. This implies that both summative and formative assessment practices are useful. The findings of Griffith (2006) suggest that such assessment practices increase students' level of mastery of subject matter as well as related skills. However, this conclusion was based on limited data and there is need for further research into Caribbean teachers' assessment practices in science.

In light of the importance of assessment in science instruction, teachers' role of decision - making regarding instructional assessment, and the need to provide information on the pattern, techniques and challenges confronting science teaching in Barbados with a view to making relevant suggestions concerning science teaching in the country, this study seeks to investigate the instructional assessment practices of secondary school science teachers in Barbados. Whether teachers are effectively assessing student learning and whether teachers are aware of good assessment practices, their various assessment practices, their knowledge and use of various assessment techniques and the challenges they encounter together with how they overcome their challenges are examined.

\section{Research questions}

I. What is the pattern of instructional assessment practices in secondary school science classes in Barbados?

2. Are there any significant differences in the instructional assessment practices of the science teachers in Barbados based on:
i. Sex?
ii. Teaching experience?
iii. Professional qualification?
iv. Academic qualification?

3. What are the instructional assessment techniques employed by secondary school science teachers in Barbados?

4. What challenges do secondary school science teachers in Barbados encounter in their instructional assessment practices?

5. How do secondary school science teachers in Barbados overcome challenges that they encounter in their instructional assessment practices?

\section{Methodology}

This research employed a cross-sectional survey design. A survey administered on only one occasion is a cross-sectional study (Gay, Mills and Airasian, 2009). Each participant was asked the same questions in the same manner (a questionnaire) so that data collected is comparable. The population is all the science teachers at all the secondary schools in Barbados. Science teachers include teachers of Biology, Chemistry, Physics, Integrated Science, Agricultural Science, and Human and Social Biology.

Twelve out of 22 secondary schools were randomly selected. All the science teachers at the twelve schools formed the sample for the study. Data were collected from fifty five secondary school science teachers (Table I). 
A questionnaire with four sections was used for data collection. Section A sought demographic information such as sex, the number of years of teaching experience, academic qualifications, subject area of specialization and professional qualifications.

Section B sought to garner teachers' self report of their assessment practices by means of 39 questions in the form of a four point Likert scale, (strongly disagree, disagree, agree and strongly agree). Both positive and negative wording was employed in the construction of the items. The items were classified into eight categories or scales (Table 2).

Section $\mathrm{C}$ of the questionnaire consists of a range of assessment techniques and teachers were required to identify each of the techniques that they use and to write the reasons for using the techniques. A similar format was used for Section D of the questionnaire where teachers were required to indicate from a list of challenges the ones which affected them and to write in the space provided how they overcome each challenge.

Table I: Characteristics of the Sample of Science Teachers $(\mathrm{N}=55)$

\begin{tabular}{llc}
\hline \multicolumn{2}{l}{ Characteristic of sample } & Frequency \\
\hline Sex & Male & 23 \\
& Female & 32 \\
Teaching experience & $0-4$ years & 13 \\
& $5-9$ years & 10 \\
& 10 - I4 years & 8 \\
& I5 - I9 years & 6 \\
& 20 years and over & 18 \\
Professional & None & 15 \\
qualification & Associate degree in education & 1 \\
& Diploma in education & 29 \\
\multirow{4}{*}{ Academic } & Certificate in educational administration & 4 \\
qualification & Advanced level & 4 \\
& Bachelor's degree & 35 \\
& Master's degree & 16 \\
\hline
\end{tabular}

Table 2: Table of specifications for Section B of the questionnaire

\begin{tabular}{|c|c|c|}
\hline Category & Questions & Sample question \\
\hline General assessment practices & $3,6,9,19,29$ & $\begin{array}{l}\text { It is not a good practice to review } \\
\text { assessment questions before administering. }\end{array}$ \\
\hline Collaborative assessment practices & $4, I 4,20,34,38$ & $\begin{array}{l}\text { I am aware of my colleagues' assessment } \\
\text { practices. }\end{array}$ \\
\hline Formative assessment practices & $10,15,23,26,27$ & I assess student learning while teaching. \\
\hline Summative assessment practices & $7, \mathrm{II}, 22,30$ & $\begin{array}{l}\text { I give assessments only at the end of a } \\
\text { lesson or unit. }\end{array}$ \\
\hline Assessment of student knowledge & $2, I 8,28,3 \mathrm{I}, 36$ & $\begin{array}{l}\text { I place heavy focus on recall of factual } \\
\text { details when I assess students. }\end{array}$ \\
\hline Assessment of student skills & $\mathrm{I} 2, \mathrm{I} 7, \mathrm{I} 3,33,37$ & $\begin{array}{l}\text { It is not possible for me to assess students' } \\
\text { use of science process skills. }\end{array}$ \\
\hline Assessment of student attitudes & $8, I, 32,35,39$ & $\begin{array}{l}\text { I contribute to the development of positive } \\
\text { attitudes to science in students. }\end{array}$ \\
\hline Assessment development process & $5,16,21,24,25$ & $\begin{array}{l}\text { When developing assessments, I clearly } \\
\text { specify the learning outcomes. }\end{array}$ \\
\hline
\end{tabular}




\section{Evidence related to validity and reliability of the instrument}

The instrument was first internally reviewed for errors and for appropriateness to gather the data required by the research questions. A university lecturer in science education also reviewed the instrument for validity. The recommended changes were made before pilot testing the instrument.

The instrument was pilot tested on twelve teachers at two schools with science teachers of similar characteristics as those forming the sample for data collection. From the responses, it was noted that most of the teachers did not complete section $\mathrm{D}$ which required teachers to write the challenges they encounter and to give how they overcome each challenge. One respondent suggested that the challenges should be listed so that teachers would just have to indicate whether or not they experience each challenge and give how they overcome it. This suggestion was adopted and the literature as well as the researcher's experience as a teacher was used to develop a list of challenges for the final draft of the instrument.

To establish internal consistency of the items in Section B, the data from the pilot study were subject to Cronbach-alpha reliability testing. The alpha value returned for the 39 item scale was 0.8622 , however one item (item 33) had a large negative coefficient (- 0.7178). This item was removed and when the reliability analysis was run again, the alpha value returned was 0.8953 .

\section{Administration of the instrument and scoring}

The instrument was administered only to science teachers and was collected after one week. The positively worded questions in section $\mathrm{B}$ of the questionnaire were scored by assigning numbers to each of the options as follows: SD- I; D- 2; A- 3; SA- 4. The negatively worded items were scored in the reverse order with $\mathrm{SD}$ being assigned 4 and $\mathrm{SA}$ being assigned I.

\section{I0. Data analysis and main findings}

\section{IO.I Data Analysis}

Data for research question one were analyzed by computing the total score for each of the assessment practice categories and recoding each score so that scores ranging from 0 -I0 were classified as not being used (disagree) by teachers and scores ranging from II-20 were classified as being used (agree) by teachers. The maximum score for each category except summative assessment practices was 20 . For the category labeled summative assessment practices, scores ranging from $0-7$ were classified as disagree and those ranging from $8-16$ as agree. This was necessary since there were only four questions in this category and the maximum score was I6. Scores falling in the disagree category were scored as I and those falling in the agree category as 2 .

To test for significant differences in the instructional assessment practices of the science teachers based on: sex, teaching experience, professional qualification and academic qualification a t-test for independent samples was run. One-way Analysis of Variance (ANOVA) was run to test for differences between assessment practice and teaching experience, professional qualification and academic qualification. Further analyses using two-way analysis of variance were carried out for checking interaction and main effects of sex, teaching experience, professional qualification, and academic qualification on teachers' assessment practices.

Data pertaining to the instructional techniques employed by the science teachers and the challenges that science teachers encounter in their instructional assessment practices were analyzed by running frequencies for the various techniques and challenges respectively. Data regarding how science 
teachers overcome challenges they encounter in their instructional assessment practices were analyzed by categorizing the solutions given for each of the challenges identified.

\section{Main findings}

\section{II.I Pattern of instructional assessment practices of secondary school science teachers}

All the teachers reported that they use collaborative assessment practices. Such practices include discussing assessments with peers before administering and learning from other teachers through sharing of ideas about assessment practices that work. Ninety-six percent of the teachers reported that they assess students' skills and follow guidelines of the assessment development process. Overall the teachers agree that they use all the instructional assessment practice categories identified in the research (Table $3)$.

Table 3: Percentage of teachers who reported using the various instructional assessment practices

$\begin{array}{ll}\text { Assessment Practice Category } & \text { Percent } \\ \text { General assessment practices } & 54.5 \\ \text { Collaborative assessment practices } & \text { I00 } \\ \text { Formative assessment practices } & 98.2 \\ \text { Summative assessment practices } & 65.5 \\ \text { Assessment of student knowledge } & 89.1 \\ \text { Assessment of student skills } & 90.9 \\ \text { Assessment of student attitudes } & 96.4 \\ \text { Assessment development process } & 96.4\end{array}$

Differences in the instructional assessment practices of science teachers based on sex, teaching experience, professional qualification and academic qualification

T-test for independent samples revealed that there are no significant differences in the instructional assessment practices of the male teachers (mean $=105, \mathrm{SD}=7.084)$ and the female teachers (mean $=$ I04.50, $\mathrm{SD}=6.584) ;(\mathrm{t}=0.269 ; \mathrm{df}=53 ; \mathrm{p}=0.789)$. Both males and females use similar assessment practices. Table 4 provides a summary of the $t$ values at the $\mathrm{p} \mathrm{(.05)} \mathrm{level} \mathrm{for} \mathrm{each} \mathrm{of} \mathrm{the} \mathrm{assessment}$ practice categories.

Table 4: Differences in assessment practice based on sex of teacher

\begin{tabular}{llllcccc}
\hline Assessment practice & Sex & $\mathrm{N}$ & Mean & Std. Dev. & $\mathrm{t}$ value & $\mathrm{F}(\mathrm{I}, 53)$ & $\mathrm{P}$ \\
\hline \multirow{2}{*}{ General practices } & Male & 23 & $\mathrm{I} 0.96$ & $\mathrm{I} .796$ & $\mathrm{I} . \mathrm{I35}$ & $\mathrm{I} .638$ & $.26 \mathrm{I}$ \\
& Female & 32 & $\mathrm{I} 0.47$ & $\mathrm{I} .39 \mathrm{I}$ & & & \\
Collaborative practices & Male & 23 & $\mathrm{I} 5.52$ & 2.108 & 0.076 & $\mathrm{I} .397$ & .939 \\
& Female & 32 & $\mathrm{I} 5.56$ & $\mathrm{I} .83 \mathrm{I}$ & & & \\
Formative practices & Male & 23 & $\mathrm{I} 5.48$ & $\mathrm{I} .780$ & 0.883 & $\mathrm{I} .957$ & $.38 \mathrm{I}$ \\
Summative practices & Female & 32 & $\mathrm{I} 5.97$ & 2.192 & & & \\
& Male & 23 & 8.57 & $\mathrm{I} .727$ & 1.227 & .703 & .225
\end{tabular}




\begin{tabular}{|c|c|c|c|c|c|c|c|}
\hline & Female & 32 & 7.94 & 1.966 & & & \\
\hline \multirow{2}{*}{ Assessment of knowledge } & Male & 23 & $\mathrm{I} 3.48$ & 1.780 & 0.039 & 3.053 & .969 \\
\hline & Female & 32 & $\mathrm{I} 3.50$ & 2.243 & & & \\
\hline \multirow[t]{2}{*}{ Assessment of skills } & Male & 23 & $\mathrm{I} 2.9 \mathrm{I}$ & 1.505 & 0.872 &. $\mathrm{IIO}$ & .387 \\
\hline & Female & 32 & 13.25 & $\mathrm{I} .344$ & & & \\
\hline \multirow{2}{*}{ Assessment of attitudes } & Male & 23 & $\mathrm{I} 3.48$ & I.082 & 0.925 & $.45 \mathrm{I}$ & .359 \\
\hline & Female & 32 & I3.I6 & I.394 & & & \\
\hline \multirow{2}{*}{$\begin{array}{l}\text { Assessment development } \\
\text { process }\end{array}$} & Male & 23 & $\mathrm{I} 4.6 \mathrm{I}$ & $\mathrm{I} .877$ & 0.095 & .004 & .925 \\
\hline & Female & 32 & $\mathrm{I} 4.66$ & I.807 & & & \\
\hline
\end{tabular}

One-way ANOVA also showed no significant differences in the teachers' instructional assessment practices and their experience, professional qualification and academic qualification. However, when the Tukey HSD Post Hoc test was run, there was a significant difference in whether teachers with $5-9$ years of experience and I0 - I4 years of experience reported using general assessment practices [F (4, $50)=2.507 ; \mathrm{P}=0.054] ;$ ( Table 5). These findings indicate that teachers with 5-9 years and I0-I4 years of teaching experience are more likely to use general assessment practices.

Table 5: Differences in Teachers' Instructional Assessment Practice and Experience, Professional Qualifications and Academic Qualifications ( $N=55$ teachers)

\begin{tabular}{|c|c|c|c|c|}
\hline Assessment Practice & & $\mathrm{df}$ & $\mathrm{F}$ & Sig. \\
\hline \multirow[t]{2}{*}{ General practices } & Between groups & 4 & \multirow{2}{*}{2.507} & \multirow{2}{*}{.054} \\
\hline & Within groups & 50 & & \\
\hline \multirow[t]{2}{*}{ Collaborative Practices } & Between groups & 4 & \multirow{2}{*}{ I.937 } & \multirow{2}{*}{.119} \\
\hline & Within groups & 50 & & \\
\hline \multirow[t]{2}{*}{ Formative practices } & Between groups & 4 & \multirow{2}{*}{.552} & \multirow{2}{*}{.698} \\
\hline & Within groups & 50 & & \\
\hline \multirow[t]{2}{*}{ Summative Practices } & Between groups & 4 & \multirow{2}{*}{1.029} & \multirow{2}{*}{.402} \\
\hline & Within groups & 50 & & \\
\hline \multirow[t]{2}{*}{ Assessment of Knowledge } & Between groups & 4 & \multirow{2}{*}{$\mathrm{I} .2 \mathrm{I} 3$} & \multirow{2}{*}{.317} \\
\hline & Within groups & 50 & & \\
\hline \multirow[t]{2}{*}{ Assessment of Skills } & Between groups & 4 & \multirow{2}{*}{.532} & \multirow{2}{*}{.713} \\
\hline & Within groups & 50 & & \\
\hline \multirow[t]{2}{*}{ Assessment of Attitudes } & Between groups & 4 & \multirow{2}{*}{.516} & \multirow{2}{*}{.725} \\
\hline & Within groups & 50 & & \\
\hline \multirow[t]{2}{*}{ Assessment Development Process } & Between groups & 4 & \multirow{2}{*}{.557} & \multirow{2}{*}{.695} \\
\hline & Within groups & 50 & & \\
\hline
\end{tabular}

Two-way ANOVA revealed significant differences in teachers' use of collaborative assessment practices and general assessment practices based on sex and teaching experience. There were five categories of teaching experience $(0-4$ years, $5-9$ years, I0 - I4 years, I5 - I9 years, and 20 years and over). For the collaborative practice category, the interaction effect between sex and teaching 
experience was not significant $[\mathrm{F}(4,45)=2.455, \mathrm{P}=0.059]$. There was no significant main effect for $\operatorname{sex}[\mathrm{F}(\mathrm{I}, 45)=0.34, \mathrm{P}=0.855]$.

A significant main effect was found for teaching experience $[\mathrm{F}(4,45)=2.605, \mathrm{P}=0.048]$ but the effect size was small (partial eta squared $=0.188$ ). While this difference may be statistically significant, it is not easily detected in practice. Post hoc comparison using the Tukey HSD test indicated that the mean score for teachers with $0-4$ years of teaching experience $(\mathrm{M}=\mathrm{I} 4.85$, $\mathrm{SD}=1.864)$ was statistically different from teachers with $\mathrm{IO}-\mathrm{I} 4$ years of teaching experience $(\mathrm{M}=\mathrm{I7} . \mathrm{I3}, \mathrm{SD}=$ I.959).

For the general assessment practice category, the interaction effect between sex and teaching experience was not significant $[\mathrm{F}(4,45)=\mathrm{I} .059, \mathrm{P}=0.388]$. There was no significant main effect for $\operatorname{sex}[F(I, 45)=0.602, P=0.442]$. No significant main effect was found for teaching experience $[F(4$, $45)=1.795, \mathrm{P}=0.146]$. Post hoc comparison using the Tukey HSD test indicated that the mean score for teachers with $5-9$ years of teaching experience $(M=9.80, \mathrm{SD}=\mathrm{I} .75 \mathrm{I})$ was statistically different from teachers with $\mathrm{IO}-\mathrm{I} 4$ years of teaching experience $(\mathrm{M}=\mathrm{I} 2.00, \mathrm{SD}=1.852)$.

The results (Table 6) suggest that female teachers with 0 - 4 years of teaching experience are more likely than males with similar experience to use collaborative assessment practices; males with I0 - I4 years of teaching experience are more likely than females with similar experience to use collaborative assessment practices and general assessment practices; and males with $5-9$ years of teaching experience are more likely than females to use general assessment practices.

Table 6: Means and Standard Deviations for Collaborative Assessments Practice and General Assessment Practices Based on Sex and Teaching Experience

\begin{tabular}{llll}
\hline Sex of Teacher & Teaching experience & Mean & $\begin{array}{l}\text { Standard } \\
\text { Deviation }\end{array}$ \\
\hline Collaborative Assessment Practice & & & \\
Male & $0-4$ years & 13.75 & 1.258 \\
Female & $0-4$ years & 15.33 & 1.936 \\
Male & I0 - I4 years & 18.75 & 1.258 \\
Female & $10-14$ years & 15.50 & 0.577 \\
General assessment practices & & & \\
Male & $5-9$ years & 10.50 & 3.536 \\
Female & $5-9$ years & 9.63 & 1.408 \\
Male & I0 - I4 years & 13.00 & 1.633 \\
Female & $10-14$ years & 11.00 & 1.408 \\
\hline
\end{tabular}

No other significant interaction or main effects between the assessment practice categories and sex, professional qualification or academic qualification were found. Therefore the results indicate that teachers' assessment practices are not significantly affected by their sex, professional qualification or academic qualification. However, whether teachers use collaborative and general assessment practices is somewhat affected by their sex and their teaching experience.

\section{II.2 nstructional techniques employed by the teachers}

The main instructional techniques used by the teachers are tests ( 52 teachers), home assignments (5I teachers), observations (43 teachers) and projects (4I teachers). A significant number of teachers (25) use checklists, a few teachers (I2) use portfolios and concept maps and very few teachers ( 8 and 7 ) reported using questionnaires and interviews respectively. 
The main reasons for using the different instructional techniques are summarized in Table 7 . The teachers' most frequent reasons for using the assessment techniques are for gauging understanding, assessing cognitive skills, reinforcing concepts taught in class, in-depth research of topics, and assessing practical skills.

Table 7: Main Reasons for Using Instructional Assessment Techniques ( $\mathrm{N}=55)$

\begin{tabular}{llc}
\hline Assessment Technique & Reason & Number of teachers \\
\hline Tests & To gauge understanding of a unit & I5 \\
& To assess cognitive skills. & 8 \\
Home assignments & To reinforce concepts taught in class & 15 \\
& To develop research skills & 9 \\
Projects & In-depth research of topics & 14 \\
& To develop research skills. & 9 \\
Observations & To develop imagination and creativity. & 7 \\
& To assess manipulative/practical skills. & I5 \\
& To identify student strengths/ weaknesses & 6 \\
Rating scales & To assess student interactions. & 5 \\
Checklists & To assess students' practical skills & 2 \\
Interviews & To assess practical skills & 10 \\
Portfolios & To identify student strengths/ weaknesses & 2 \\
& To assess organizational skills & $\mathrm{I}$ \\
Concept maps & To assess creative skills & $\mathrm{I}$ \\
& To assess students ability to link concepts & 3 \\
& As an advance organizer & 2 \\
\hline
\end{tabular}

II.3 Science teachers' challenges in their instructional assessment practices and methods of overcoming their challenges

The teachers identified four of the listed challenges as common to their instructional assessment practices. The challenges identified are; time constraints not allowing completion of syllabus objectives, assessment of practical skills not possible due to large classes and lack of materials, and not having time to carefully plan assessment procedures. None of the teachers experienced difficulty in constructing test items that test syllabus objectives or difficulty in developing marking schemes. The major methods given by teachers for overcoming specific instructional assessment challenges are shown in Table 8.

Table 8: Teachers' Instructional Assessment Challenges and how they overcome the challenges

\begin{tabular}{|c|c|}
\hline Challenge & Method of overcoming challenge \\
\hline \multirow{4}{*}{$\begin{array}{l}\text { Time constraint do not allow assessment of all syllabus } \\
\text { objectives }\end{array}$} & Use of projects \\
\hline & Lunch time/ vacation classes \\
\hline & Home assignments \\
\hline & Selection of most important objectives \\
\hline Classes are too large to assess practical skills & Group work \\
\hline \multirow{4}{*}{$\begin{array}{l}\text { Lack of materials and/or apparatus limit my assessment } \\
\text { of the students practical skills }\end{array}$} & Purchasing or borrowing materials \\
\hline & Using group work \\
\hline & Demonstrations \\
\hline & Use of inexpensive and recycled materials \\
\hline $\begin{array}{l}\text { I do not have the time to carefully plan assessment } \\
\text { procedures. }\end{array}$ & Use of the same procedure over and over \\
\hline
\end{tabular}


The use of group work, lunch time/vacation classes and purchasing or borrowing of materials were the most frequent ways given for overcoming the challenges identified.

Single teachers gave other methods of overcoming their instructional assessment challenges as; giving handouts, reducing the number of practical activities, and using stations when materials are lacking.

\section{Discussion of results}

The findings of this study suggest that the assessment practices of science teachers in Barbados span general, collaborative, formative, and summative assessment practices while assessing students' knowledge, skills and attitudes. Several implications arise from these findings. The finding that the teachers reported using collaborative assessment practices imply that they discuss assessment questions critically with their peers, they are aware of their colleagues' assessment practices, they share ideas with other teachers and learn from each other. Wiggins (1992) also claims that teachers can help each other by sharing assessment task ideas. This claim is somewhat supported by the techniques that the teachers report using.

The techniques used most often by the teachers are tests, home assignments, projects, observations and checklists. The majority of teachers used tests to assess cognitive skills however, it is purported by Wiggins (1992) that tests usually over-assess knowledge and under-assess 'know how with knowledge'. Effective use of tests requires teachers to be familiar with diverse test items and to know how to use each type of test item for assessing a variety of cognitive processes (Chiappetta et al. 1998). The authors claim that tests tend to reveal what students do not know instead of what they know and can do and focus mainly on isolated facts whereas the focus of learning is directed towards relevant future oriented content. The only two reasons given by the teachers for using tests were to gauge understanding of a unit of work and to assess cognitive skills. These reasons may suggest that the teachers do not use a variety of tests as indicated by Chiappetta et al. (1998) and that these tests do not assess the psychomotor or affective domains.

There is great demand for accountability (value for money) which tests do not necessarily achieve. A high test score is not a true measure of instructional effectiveness as there are many other influencing factors. Tests (paper and pencil) do not match learning theories which promote individual differences in learning style and do not actively involve students in the assessment process. These, among other factors contribute to the disadvantages of paper and pencil tests so commonly used in the Caribbean and indeed globally.

On the other hand, tests provide teachers with opportunity to discuss test items with their colleagues as well as share ideas and learn from each other. Tests also provide teachers with an easily administered technique for assessing student knowledge. Given the multiple tasks of teachers, they would welcome an easily administered, less time consuming method of assessing student learning. Although the teachers did not report this, they may well be using tests to overcome the challenges of: insufficient time to complete the syllabus, large classes, lack of materials and insufficient time to plan a variety of assessment techniques.

The use of projects in instructional assessment can: be authentic; integrate understanding, skills and strategies; involve students in self-assessment and independent learning; help students develop generalizable skills; foster collaboration among teachers and students; and motivate as well as challenge students (Gronlund 2006). None of these reasons were given by the teachers for selecting projects as a form of assessment. This suggests that teachers use projects predominantly as a method of overcoming the challenge of time constraints (Table 7) and may not be aware of the benefits of using projects to improve teaching and learning. 
Extensive evidence that formative assessment improves learning was provided by Black and Wiliam (1998). Formative assessment throughout instruction can provide feedback to help students improve their learning (Chiappetta et al. 1998). Teachers' use of formative assessment practices suggests that they: provide opportunity for individual learning, assess student learning while teaching, give students feedback to improve learning, and use assessment results to reveal students' weaknesses.

The use of home assignments by many teachers (5I) may promote individual learning, but the teachers gave reasons such as, to reinforce concepts taught in class and to develop research skills. Home assignments may not be fully effective in promoting individual learning as students may receive too much assistance and this can give the teacher a false impression of student learning. Despite this disadvantage, giving students home assignments can help students to: develop critical thinking skills, become self motivated to learn, share their knowledge with other family members and/or learn from other family members, and to be more creative. The finding that many teachers overcome their instructional assessment challenges by assigning group work (Table 8) can also hinder individual learning.

Students' attitudes, interests and values significantly affect their future behaviour and learning (Popham 2008). The science teachers in the study saw the importance of assessing students' attitudes as well as their scientific attitudes. This contrasts the view of Popham (2008) that few teachers assess students' attitudes and values.

The teachers also clearly indicated that they specify the learning outcomes and match their assessments to the learning outcomes, develop assessments that provide meaningful information, develop clear scoring criteria and guidelines for administering assessments. Such practice reflects current trends in instructional assessment and the assessment standards developed by the National Research Council.

The finding that teachers assess students' skills implies that they: use hands-on experiences in their assessments, allow students opportunity to display their skills, assess students' use of science process skills and see value in assessing students' skills. The techniques of observations and checklists which are often used in assessing skills were used by many teachers, however rating scales which is more time consuming to develop and use were rarely used. Many teachers (43) reported using observations to assess students' practical skills and to gain insight into students' strengths and weaknesses. A systematic procedure is needed to keep track of observations and the process can be time consuming in addition to increasing test anxiety in some students (Good et al. 2008).

More teachers reported using checklists than rating scales. While checklists are useful in assessing procedures, products, behaviours and as a self-evaluating tool (Gronlund 2006; Nitko 2004), they only indicate whether a step, property or action is present. Rating scales (not often used by teachers) on the other hand, are useful in both teaching and assessing, to show the degree a student has attained a learning target, and to help the teachers see the growth of each student (Nitko 2004). The reasons given by the teachers (Table 7) suggest that they either are not aware of these advantages of rating scales or they lack expertise in developing rating scales.

One limitation of the instrument is that it was not possible to include skills such as communication, reasoning, and presentation. The use of interviews and observations would have provided richer data in terms of clarifying teachers' conceptions of skills. Due to the quantitative nature of this research, the use of these instruments was not explored.

The science teachers assess knowledge more than any other kind of learning outcomes and place heavy emphasis on the assessment of facts, concepts, principles, laws and theories. The findings do not indicate the nature of such assessments and further research is necessary to establish just what knowledge teachers assess and what value they ascribe to what they assess. Peer assessment, also used by the teachers is important as some students may be more willing to receive feedback from their peers than from 
teachers (Parkay et al. 2010). In addition, the authors report that self assessment is useful for allowing students to recognize factors that may promote or hinder their learning.

The teachers practiced using summative assessments to quite a large extent. While summative assessments are useful in assessing a range of behaviours, skills and knowledge (Chiappetta et al. 1998), Trowbridge et al. (2004) caution that teachers should use a variety of assessment techniques. Although the assessment practices of the teachers are varied and reflect current trends in instructional assessment, it is important that teachers master the principles of appropriate classroom assessment for productive school improvement (Stiggins I995). Achieving assessment literacy require teachers to know what, why, and how they assess, as well as anticipating and addressing problems that may arise in their assessment practices (Stiggins I995).

Interviews, portfolios and concept maps are rarely used by teachers despite the many benefits of these techniques. Interviews assess quality and extent of learning in science (Abdullah et al. 1997), and give teachers insight into student thinking and understanding (Chiappetta et al. 1998). Portfolio assessments foster in students the skills of selecting, organizing, synthesizing, summarizing, collaborating with others, and reflecting (Adams et al. 1992; Chiappetta et al. I998; Good et al. 2008; Gronlund 2006; Trowbridge et al. 2004). Again, the challenges of time and large classes identified by the teachers may be the reasons why they rarely use these techniques. If teachers do not have the time to review multiple drafts of portfolios and provide individual feedback to students or small groups of students, then portfolios may not be the choice of assessment. The use of interviews is also time consuming and requires management skills on the part of the teacher. For instance, what happens to the rest of the class when the teacher is interviewing a student or group of students may be a major concern to the teacher.

Concept mapping has proved particularly useful in both assessment and instruction in science education. It is surprising that very few science teachers use this technique. Concept maps are used to show meaningful relationships between science concepts, to reveal students' conceptions before and after instruction and to indicate growth in understanding (Chiappetta at al. 1998; Trowbridge et al. 2004). Lack of teacher knowledge of these techniques could be responsible for their very scarce use in the classroom. This is indicated by the two reasons (to assess student ability, and as an advance organizer) given by the teachers for using concept mapping.

The challenges in instructional assessment identified by the teachers are systemic in nature. While the methods that teachers employ to overcome their instructional assessment challenges may provide temporary solutions, it is necessary to approach these challenges at the institutional level. Teachers tend to devise ways of coping with their overload and multiple demands from policy makers, administrators, parents and students. However, the reasons indicated for using the various techniques suggest teachers' lack of knowledge and experience in using these techniques. Teachers appear to attend to immediate practical and contextual challenges rather than theoretical or propositional knowledge (Marx et al. 1994).

Brooks and Brooks (200I, 3) maintain that "questions regarding understanding and meaning and the roles that schools play in encouraging or stifling the search for understanding are far more important to many educators than questions regarding achievement as measured by test scores". It is suggested that assessment practices be overhauled to make assessments more relevant to students.

The finding that sex, teaching experience, professional status and academic performance do not significantly affect teachers' instructional assessment practices seem to support the suggestion by $\mathrm{Mc}$ Millan (2007) and Sato et al. (2007) that teachers' beliefs and attitudes highly affect their assessment practice decisions. Research into the assessment practices of the teachers' previous teachers may provide insight into whether teachers' assessment practices reflect how they were assessed as students. It is worth noting that female teachers with less teaching experience and male teachers with more teaching experience are more likely to engage in collaborative assessment practices. This finding implicate female 
teachers as being more open minded regarding collaboration with colleagues, however further research is necessary before drawing conclusions on this issue. The finding that males with $5-9$ years of teaching experience are more likely to use general assessment practices may indicate the need for ongoing professional development activities to address teachers' instructional assessment needs.

\section{I3. Implications}

Teachers' instructional assessment practices were not significantly influenced by their sex, teaching experience, professional status or academic qualification; and the techniques used as well as the reasons for using the techniques did not reflect teachers' application of theoretical knowledge. As other researchers (Anderson 2002; Blumenfeld et al. 1994; Bol et al. I996; Marx et al. I994; Osborne et al. 2003) have proposed, I suggest that science teachers' instructional assessment practice reflect what is practical in their classroom contexts. Teachers should focus on what is practical in their classroom instead of applying theory to practice (Blumenfeld et al. 1994). In light of the potential benefits of science teachers' instructional practices compared to the reasons that the teachers gave for using the various techniques, it appears that teachers do not realize that their assessment practices are incongruent to science instructional goals (Bol et al. 1996). The techniques should be appropriate for developing students' science inquiry skills and for allowing students opportunity for constructing knowledge. From the findings, the teachers do know the appropriate instructional assessment practices for improving teaching and learning, and it is also clearly apparent that the reasons given for using the various techniques show their ineffectiveness in assessing student learning in science. It appears that the teachers select the most easily administered assessment techniques instead of the technique which will result in improved teaching and learning.

The teachers gave idiosyncratic ways of overcoming their instructional assessment challenges although the challenges they identified were mainly systemic in nature and they reported a high degree of collaboration in their instructional assessment practice. This implies that teachers need help in addressing their instructional assessment needs from a systemic approach.

\section{Recommendations}

Based on the findings of this research and previous research reported in the literature, the researcher recommends that more attention be directed towards providing professional support for practicing teachers to have opportunity for reflective and collaborative practice. Such opportunities should: focus on practical challenges that teachers face in their own classrooms (Anderson 2002; Osborne et al. 2003), be long term ( Henze et al. 2007; Marx et al. 1994), and benefit both teachers and facilitators (Blumenfeld et al. 1994). Teachers need opportunities to consider their practice and how they may improve their practice. This approach was successful in getting teachers to change their assessment practices as indicated in the Classroom Assessment Project to Improve Teaching and Learning (CAPITAL) (Atkin et al., 2005)

\section{References}

Abdullah, A., and J. Scaife. I997. "Using interviews to assess children's understanding of science concepts." School Science Review 78(285): $79-84$.

Adams, D.M., and M.E. Hamm. 1992. "Portfolio assessment and social studies: collecting, selecting and reflecting on what is significant." Social Education February: I03 - I05. 
Anderson, R.D. 2002. "Reforming science teaching: what research says about inquiry?" Journal of Science Teacher Education I3(I): I - I2.

Atkin, J. Myron, Janet E. Coffey, Savitha Moorthy, Mistilina Sato and Matthew Thibeault. 2005. Designing everyday assessment in the science classroom. New York: Teachers College Press.

Bass, J.E., T.L. Contant, and A.A. Carin, 2009. Teaching science as inquiry. Boston MA: Allyn and Bacon.

Bell, B. 2007. "Classroom assessment of science learning." In Handbook of research on science education, edited by S.K. Abell. \& N.G Lederman, New York: Routledge.

Black, P. and D. Wiliam. 1998. "Assessment and classroom learning." Assessment in Education 5(I): 7 - 74.

Blumenfeld, P.C., J.S. Krajcik, R.W. Marx, and E. Soloway. I994. "Lessons learned: How collaboration helped middle grade science teachers learn project-based instruction.” The Elementary School Journal 94(5): 539 $55 \mathrm{I}$.

Bol, L. and A. Strage. 1996. "The contradiction between teachers' instructional goals and their assessment practices in high school Biology courses." Science Education 80(2): I45 - I63.

Brooks, J.G. and M.G. Brooks. 200I. In search of understanding. The Case for constructivist classrooms. New Jersey: ASCD.

Chiappetta, E.L., T.R. Koballa and A.T. Collette. 1998. Science instruction in the middle and secondary schools. Upper Saddle River, New Jersey: Merrill Prentice Hall.

Clymer, J.B. and D. Wiliam. 2007. "Improving the way we grade science." Educational Leadership December 2006/January 2007: $36-42$.

Cowie, B., \& B. Bell. 1999. "A model of formative assessment in science education.” Assessment in Education 6(I): I02-II6.

Gay, L.R., G.E. Mills, and P. Airasian 2009. Educational Research competencies for analysis and applications. Columbus, Ohio: Pearson.

Good, T.L. and J.E. Brophy. 2008. Looking in classrooms. Boston, MA: Pearson.

Griffith, S.A., 2006. "Where constructivism meets behaviourism. Issues in the design of a teacher education course in classroom assessment." Caribbean Journal of Education 28(2): I44 - I62.

Gronlund, N.E., 2006. Assessment of student achievement. Boston, MA: Allyn and Bacon.

Henze, I., J. Van Driel, and N. Verloop. 2007. "The change of science teachers' personal knowledge about teaching models and modeling in the context of science education reform." International Journal of Science Education 29(I5): I8I9 - I846.

Liu, K., I995. "Allowing students to assume responsibility for the quality of their work. Rubrics revisited." The Science Teacher 62(7): 49-51.

Loucks-Horsley, S., 1989. "Science Assessment: What it is and what it might be." Educational Leadership 46(7): 86.

Marx, R.W., P.C. Blumenfeld, J.S. Krajcik, M. Blunk, B. Crawford, B. Kelly, and K.M. Meyer. 1994. "Enacting project-based science: Experiences of four middle grade teachers.” The Elementary School Journal 94(5): 5 I7 $-538$.

McMillan, J. H. 2007. Classroom assessment Principles and practice for effective standards-based instruction. Boston: Pearson.

National Research Council. 1996. "National science education standards." Retrieved February OI, from http://nap.edu/catalog/4962.html.

Nitko, A.J., 2004. Educational assessment of students. Upper Saddle River New Jersey: Pearson.

Osborne, J., M. Ratcliffe, and H. Bartholomew. 2003. "Teaching pupils 'ideas-about-science': case studies from the classroom." Paper presented at the Biennial Conference of the European Association for Research in Science Education, Amsterdam, August $20-23$.

Parkay, F.W., G. Hass, and E.J. Anctil. 2010. Curriculum leadership. Readings for developing quality educational programs. Boston, MA: Allyn and Bacon.

Popham, J.W., 2008. Classroom Assessment What teachers need to know. U.S.A: Pearson.

Radford, D.L., L.L. Ramsey, and W.C. Deese. 1995. "Demonstration assessment: Measuring conceptual understanding and critical thinking with rubrics.” The Science Teacher 62(7): 52 - 55. 
Ratcliffe, M. and P. Hanley. 2005. "Evaluation of professional development strategies for bringing contemporary science into the classroom." Paper presented at European Science Education Association Conference, Barcelona.

Reynolds, C.R., R.B. Livingston, \& V. Willson. 2009. Measurement and Assessment in Education. Upper Saddle River New Jersey: Pearson.

Sato, M. and M.J. Atkin. 2007. "Supporting teacher change in classroom assessment." Educational Leadership, December2006/January 2007: 76-79.

Stiggins, R., I995. “Assessment literacy for the 21 ${ }^{\text {st }}$ Century.” Phi Delta Kappan 77(3): 238 - 245.

Trowbridge, L.W., R.W. Bybee, and J.C. Powell. 2004. Teaching secondary school science. Strategies for developing scientific literacy. Upper Saddle River, New Jersey: Pearson.

Wiggins, G. 1992. "Creating tests worth taking.” Educational Leadership 49(8): 26 - 33.

Yin, R.K., 2003. Case study research: design and methods. Applied Social Research Methods series, Volume 5. Thousand Oaks, CA: Sage. 
